\title{
Phenology and fruit set comparison of camu-camu (Myrciaria dubia) in a natural population and a plantation in the central Amazon, Brazil
}

\author{
Grace Anne Coelho FERREIRA ${ }^{1 *}$, , Adrian Paul Ashton BARNETT ${ }^{1}$, Cristiane KRUG ${ }^{2}$ \\ ${ }^{1}$ Instituto Nacional de Pesquisas da Amazônia - INPA, Av. André Araújo 2936, Petrópolis, Manaus, Amazonas, Brazil \\ 2 Embrapa Amazônia Ocidental, Rodovia AM-010, Km 29, Manaus, Amazonas, Brazil \\ * Corresponding author: graceanne7@gmail.com; (D) https://orcid.org/0000-0002-0867-2309
}

\begin{abstract}
Myrciaria dubia (Myrtaceae) is a shrub that produces fruits with high concentrations of ascorbic acid (1380 to 1490 mg 100 $\mathrm{g}^{-1}$ of pulp and $2050 \mathrm{mg} 100 \mathrm{~g}^{-1}$ of peel), 20 times more than acerola and 100 times more than lemon. Native to the Amazon region, it occurs naturally on the seasonally-flooded banks of lakes and rivers, but also has been cultivated commercially in terra firme. In this study, phenological observations and fruit yield evaluations were carried out in a natural population of camu-camu in a floodplain habitat and a plantation in terra firme in central Amazonia. Biweekly visits were made over one year to collect data on flowering, fruiting and leaf phenology. At the height of flowering, flower buds were marked and tracked until fruit matured and were harvested for biometrics and seed counting. Fruits varied from 1.01 to $2.73 \mathrm{~cm}$ in diameter and 1.14 to $10.87 \mathrm{~g}$ in weight and fruit production was higher in the wild stand. Phenology differed between habitats and phenophase synchrony was higher in the natural population. Despite being native to flooplain forests, fruit production in terra firme occurred throughout the year, suggesting that there are few restrictions on fruit development in cultivated plantation.
\end{abstract}

KEYWORDS: flowering, fruit yield, floodplain forest, terra firme, Myrtaceae

\section{Comparação da fenologia e produção de frutos de camu-camu (Myrciaria dubia) entre uma população natural e uma plantação na Amazônia- central, Brasil}

\section{RESUMO}

Myrciaria dubia (Myrtaceae) é um arbusto que produz frutos com altas concentraçóes de ácido ascórbico (1380 a 1490 mg $100 \mathrm{~g}^{-1}$ na polpa e $2050 \mathrm{mg} 100 \mathrm{~g}^{-1}$ na casca), 20 vezes mais que a acerola e 100 vezes mais que o limáo. Nativo da região amazônica, ocorre naturalmente em ambientes sazonalmente inundados, nas margens de lagos e rios, mas também é cultivado comercialmente em terra firme. Neste estudo, observaçóes fenológicas e avaliação da produtividade de frutos foram realizadas em uma população natural de camu-camu em ambiente inundável e em uma plantação em terra firme, na Amazônia central. Visitas quinzenais foram feitas durante um ano para coleta de dados sobre floração, frutificação e fenologia foliar. No auge da floração, os botóes florais foram marcados e acompanhados até a maturação dos frutos, que foram colhidos para biometria e contagem das sementes. Os frutos variaram de 1,01 a 2,73 cm em diâmetro e 1,14 a 10,87 g em peso, com maior produçáo de frutos em ambiente natural. A fenologia diferiu entre os habitats e a sincronia das fenofases foi maior na população natural. Apesar de ser nativo de florestas inundáveis, a produção de frutos em terra firme ocorreu ao longo do ano, sugerindo que há poucas restriçóes para o desenvolvimento de frutos em cultivo.

PALAVRAS-CHAVE: floração, produção de frutos, floresta inundável, terra-firme, Myrtaceae

\section{INTRODUCTION}

The Amazon rainforest is an important center for global fruit species diversity (Chagas et al. 2014). Among these, the camu-camu, Myrciaria dubia (Kunth) McVaugh (Myrtaceae) stands out, as it produces fruits with high concentrations of ascorbic acid (1380 to $1490 \mathrm{mg} 100 \mathrm{~g}^{-1}$ of pulp and $2050 \mathrm{mg}$ $100 \mathrm{~g}^{-1}$ of peel), which is about 20 times more than in acerola, Malpighia emarginata DC., and up to 100 times more than in lemon, Citrus limon (L.) Osbeck (Vidigal et al. 2011). It also contains $\beta$-carotenes, phenolic compounds, some amino acids and minerals (Barros et al. 2018). Therefore, the pulp of 
camu-camu and its various by-products have aroused interest in several commercial sectors (Yuyama et al. 2002).

Camu-camu is a shrub reaching up to $7 \mathrm{~m}$ in height (Barros et al. 2018), with axillary inflorescences, hermaphroditic polystemous flowers with inferior ovary, white petals and a pleasant sweet smell (Maués and Couturier 2002). Flowers last for a single day, pollen grains are small compared to other Myrtaceae and have a dry, granular, surface (Maués and Couturier 2002). Individual camu-camu shrubs fruit annually. The fruit is a rounded smooth and shiny berry, with a red to purple hue when ripe (Barros et al. 2018).

Camu-camu is widely distributed in the Venezuelan, Peruvian, Colombian and Brazilian Amazon. It occurs naturally in seasonally-flooded environments, such as floodplain forests, and along the banks of lakes (Maués and Couturier 2002). Camu-camu was first commercially cultivated in Peru, which remains the largest producer and exporter of these fruit (Abanto-Rodriguez et al. 2014). In Brazil, camu-camu cultivation is concentrated in the states of Amazonas, Pará and São Paulo (Silva and Oliveira 2018). The species is considered to be in the process of domestication (Pinto et al. 2020).

Studies of phenophases and their variability provide important data for the improvement of fruit productivity and quality, as phenological patterns of tropical species are associated with abiotic factors, including rainfall and temperature (Marques et al. 2004), and every plant species behaves differently under particular environmental conditions (Segantini et al. 2010). It is necessary to monitor phenological patterns of a species, not only to understand its life cycle, but also how phenology influences the activity of pollinators, dispersers, herbivores and pathogens that interact with the plant community of which that species is part (Wallace and Painter 2002).

In the Brazilian Amazon there has, to date, been no comparison of the phenology and fruit set of natural and cultivated populations of camu-camu. Therefore, our objectives were to: (i) compare the phenological aspects of camu-camu in floodplain and terra firme environments; (ii) compare the number of fruits produced in each area; and (iii) quantify the characteristics of the fruits in each area.

\section{MATERIAL AND METHODS}

\section{Study area}

Observations were made in two locations in Amazonas state, Brazil (Figure 1): (1) native habitat of the species in a floodplain area, located at Chácara Mariju $\left(3^{\circ} 5^{\prime} 39.37\right.$ "S; $60^{\circ} 22^{\prime} 11.08^{\prime \prime W}$ ), at $\mathrm{km} 29$ along state highway AM-070, in the municipality of Iranduba, where a large natural mono-
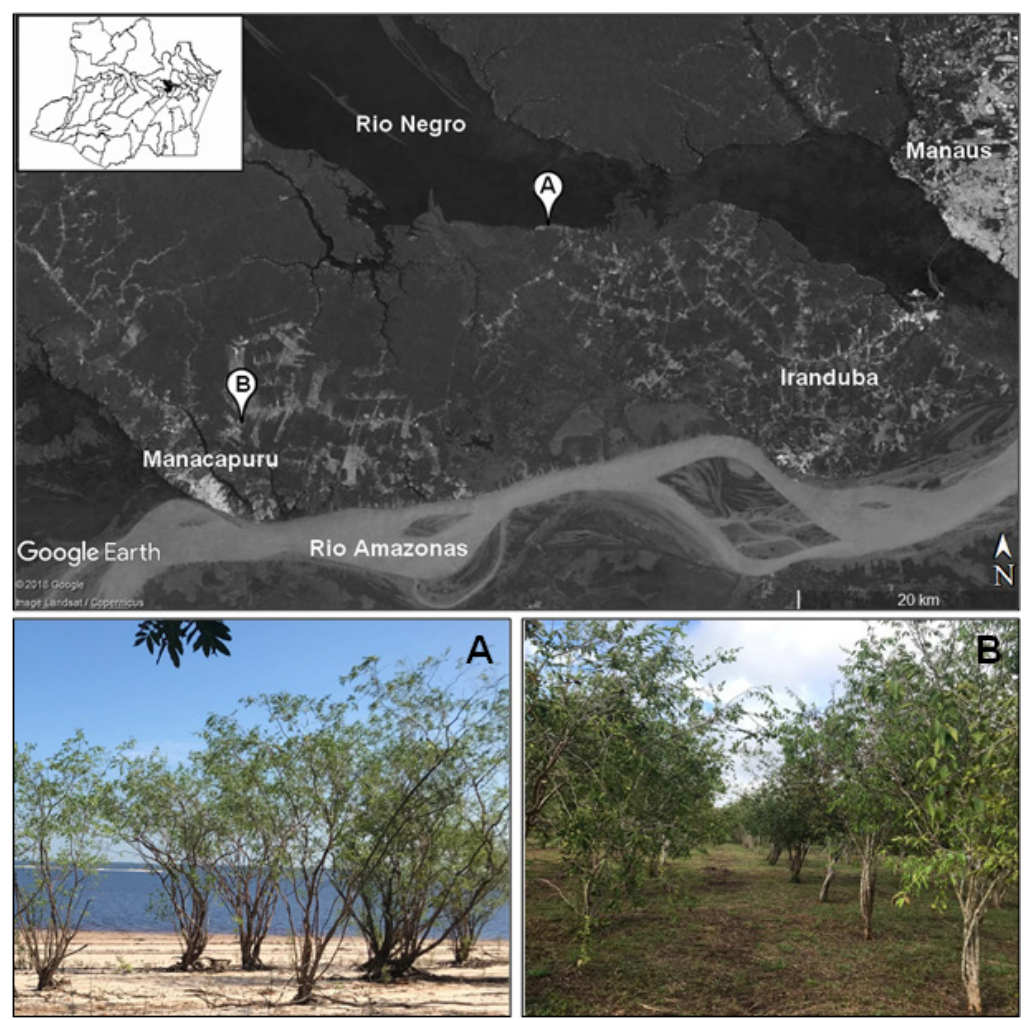

Figure 1. Location of the two camu-camu, Myrciaria dubia study sites along the AM-070 highway, Amazonas state, Brazil. A - Chácara Mariju, Iranduba municipality; B - KXK Agroindústria, Manacapuru municipality. Modified from Google Earth. This figure is in color in the electronic version. 
specific population grows along the shore of the Negro River. The area is subject to seasonal flooding during the high water of the river, as is characteristic for the region (Pires and Prance 1985); and (2) a camu-camu plantation in an area of terra firme (terrain that is never flooded) belonging to KXK Agroindustry ( $3^{\circ} 14^{\prime} 17.09^{\prime \prime}$; $\left.60^{\circ} 36^{\prime} 1.31^{\prime \prime W}\right)$, at km 70 along state highway AM-070, in the municipality of Manacapuru. The plantation comprises approximately 1,800 individual camu-camu plants of varied origin that were planted in 2007. The native population does not receive any type of cultural or pruning treatment. The plantation receives minimal treatments and maintenance, including chemical fertilization and pruning at least once a year, and the elimination of weeds between the planted rows, without using pesticides, according to the landowner.

The regional climate is classified as Af (tropical humid), according to the Köppen (1948) classification, characterized by an average annual temperature of $26^{\circ} \mathrm{C}$, with the coldest month temperature exceeding $18^{\circ} \mathrm{C}$, and annual average precipitation greater than $2,500 \mathrm{~mm}$. Highest temperatures occur between August and October. April and October are the months of transition between the seasons. In 2019 it reached approximately $35^{\circ} \mathrm{C}$ in October. Highest rainfall occurs in the first quarter of the year, and in 2019 rainfall reached 1028.8 mm (INMET 2019).

\section{Phenology}

To record phenological patterns (Figure 2), 20 individuals in the natural population and 52 from the plantation were marked and monitored during visits every other week for 13 months (August 2018 to September 2019). The sample size in the natural population was limited by the individuals that could be assessed at high water level. The following data were recorded: flowering (presence of floral bud or flowers), fruiting (green fruits, ripe fruits, drop fruits) and leaf changes (new leaves, old leaves and leaf drop). Each evaluated plant located in an area received a number from 0 to 4 based on crown cover, where $0=$ phenophase absent, $1=1$ to $25 \%, 2$ $=26$ to $50 \%, 3=51$ to $75 \%$, and $4=76$ to $100 \%$, based on the methodology of Fournier (1974). A voucher specimen was deposited in the herbarium of Instituto Nacional de Pesquisas de Amazônia (Accession number 287337).

\section{Fruiting}

At the peak of flowering (October-December), 100 flower buds ( 25 buds per branch) were randomly selected and marked on 10 different camu-camu plants (total $=1000$ flower buds) in each population. Buds were individually identified with loops of colored ribbon and were monitored every 15 days until fruits matured. Once mature, fruits were harvested and individually identified by the number and

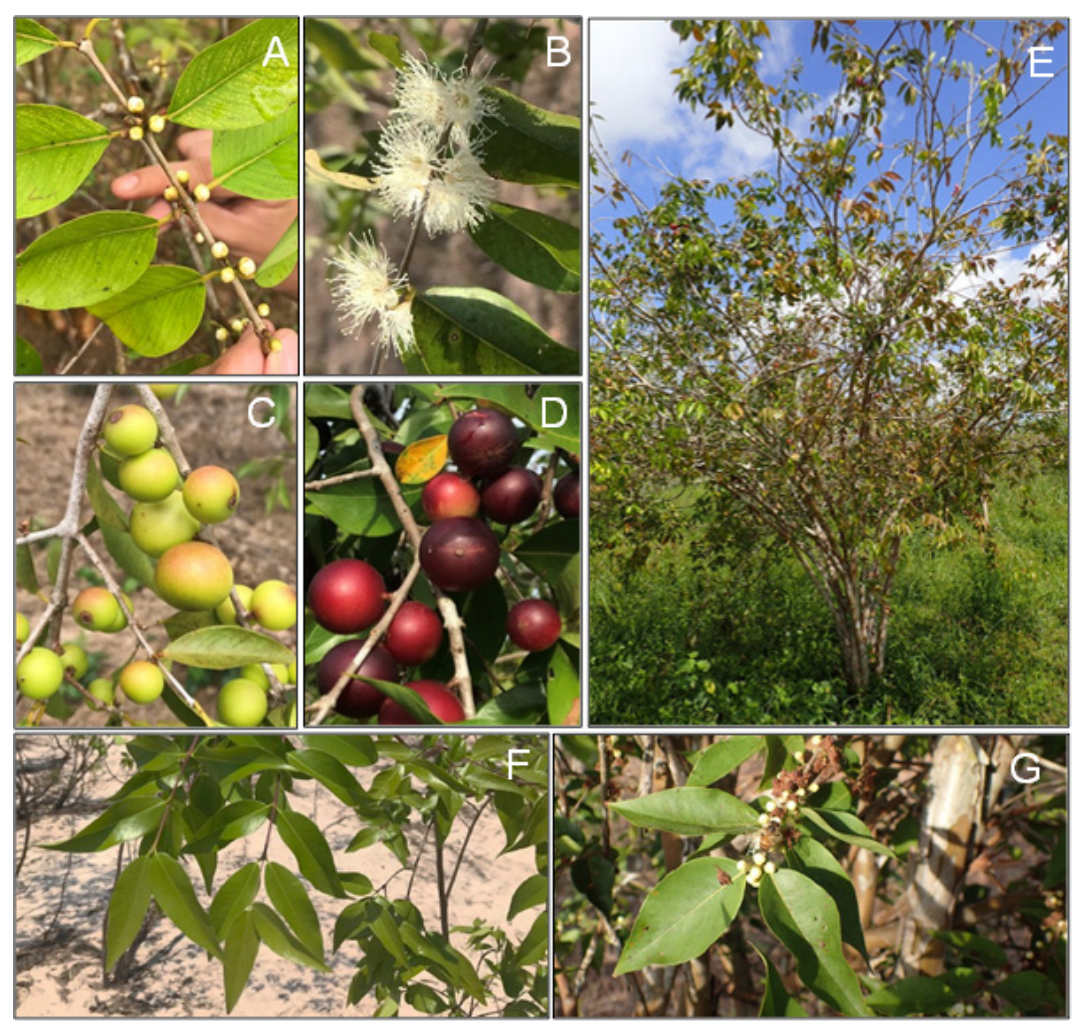

Figure 2. Phenological aspects of camu-camu, Myrciaria dubia. A - flower buds; B - flowers; C - green fruits; D - mature fruits; E - leaf drop; F - new leafs; G - mature leafs. This figure is in color in the electronic version. 
branch of the plant, and harvest date. Fruits were harvested when their color reached red to dark purple, an indication of the final stage of maturation (Barros et al. 2018). Fruits were individually weighed on a digital scale, and measured for maximum diameter with a caliper. The number of seeds per fruit was counted.

\section{Meteorological data}

Rainfall, temperature and relative humidity data for the period of phenological observations were obtained from Instituto Nacional de Meteorologia (INMET, www.inmet.gov.br). For Iranduba, we used data from the Conventional Meteorological Station in Manaus, approximately $34 \mathrm{~km}$ south of the study site, the station closest to the study site. For Manacapuru, we used data from the Automated Meteorological Station at Manacapuru.

\section{Data analysis}

For phenology, the activity index was calculated as the percentage of individuals in the population with a given phenological stage per month. Phenophase intensity was calculated via a Fournier index (Bencke and Morellato 2002), described as

$\%$ Fournier $=\sum(\mathrm{Fi}) / 4 \mathrm{~N} \times 100$

where:

$\mathrm{Fi}=$ sum of individual Fournier intensity categories; $\mathrm{N}=$ total number of observed plants.

A mixed linear model was used to minimize the difference in sample sizes, as it allows for nested random effects and the residues can be correlated (Pinheiro et al. 2007). For analysis of flowering the presence or absence of flowers was used, and for analysis of fruiting, the presence or absence of ripe fruits was used. We combined the phenological observations per month with the corresponding climatic data for each study area, and modeled the relationships between the variables using mixed linear effects (lme). For each interaction, climatic variables were used as an explanatory variable (fixed effects), while phenophases of individuals were used as a response variable (random effect) based on the model (2).

Models were built using the "nlme" package in statistical program R Version 1.1.463 (Pinheiro et al. 2007; R Development Core Team, 2012).

Flowering or Fruiting $=\alpha+b_{a}+\beta * C V+\varepsilon_{a}$

where:

$\alpha=$ fixed intercept $b_{a}=$ environment individuals observations; $\beta=$ angular coefficient of each environmental variable; $C V=$ climatic variable (rainfall, temperature and humidity relative); $\varepsilon_{\mathrm{a}=}$ model error (residuals)
Fruiting success (the proportion of flowers that developed ripe fruit) was calculated for each area as the ratio between the number of ripe fruit and marked flowers. From the information provided from harvested fruits, dispersion measures for size, weight and number of seeds were calculated. A Spearman coefficient $\left({ }_{r} S\right)$ was used to evaluate the correlation between weight and diameter $(\mathrm{p}<0.05)$, using per plant data from each separate area. Statistical analyzes were performed using the R program (R Development Core 159 Team, 2012).

Mean fruit weight and diameter per camu-camu individual were calculated and converted into categories for comparison between areas: light ( 0 to $2.5 \mathrm{~g}$ and 0 to $0.8 \mathrm{~cm}$ ), medium (2.6 to $5 \mathrm{~g}$ and 0.9 to $1.6 \mathrm{~cm}$ ) and heavy (5.1 to $7 \mathrm{~g}$ and 1.61 to $2.4 \mathrm{~cm}$ ). For seeds, the categories were the number of seeds per fruit.

\section{RESULTS}

Both precipitation and phenology patterns differed between the natural population and plantation. In the floodplain area, precipitation showed two annual peaks, between December and January, and in May, while in the terra firme area there was a single peak during February-March. It rained heavily in both areas between December and May. In the floodplain area, rainfall remained above $250 \mathrm{~mm}$ in these months, but in the terra firme area rainfall started above $350 \mathrm{~mm}$ and declined rapidly in February $(196 \mathrm{~mm})$, then gradually increased again until May.

\section{Flowering}

In the natural population, flower buds formed between October and February. Synchrony among individuals was higher in November and December, at the beginning of the rainy season, when $80 \%$ of the shrubs had flower buds at the same stage of development. The Fournier index was also higher in these two months, reaching $23.8 \%$ in November and $33.1 \%$ in December (Figure 3a).

In the plantation, flower buds formed in almost every month of the study period, except February and August 2019. Flower bud production was highest in October, when the Fournier index reached $36.8 \%$. In June and July, the Fournier index was $8.89 \%$ and $5.28 \%$, respectively. In the other months, the index did not exceed 5\% (Figure 3b).

In the natural population, flowering occurred only between November and January, coinciding with the period of increased rainfall. Flower buds started opening before river water levels began to rise in November. By December, when the rainfall peaked at $349.7 \mathrm{~mm}$, almost all the camu-camu plants were in bloom. Flowering during the rainy season in December (activity index 72.5\%), was followed by a swift decline with no flowering at all in March (Figure 3c).

In the plantation, camu-camu flowered throughout almost the entire study period and flowering peaked between October and January, when the Fournier index and activity indices 


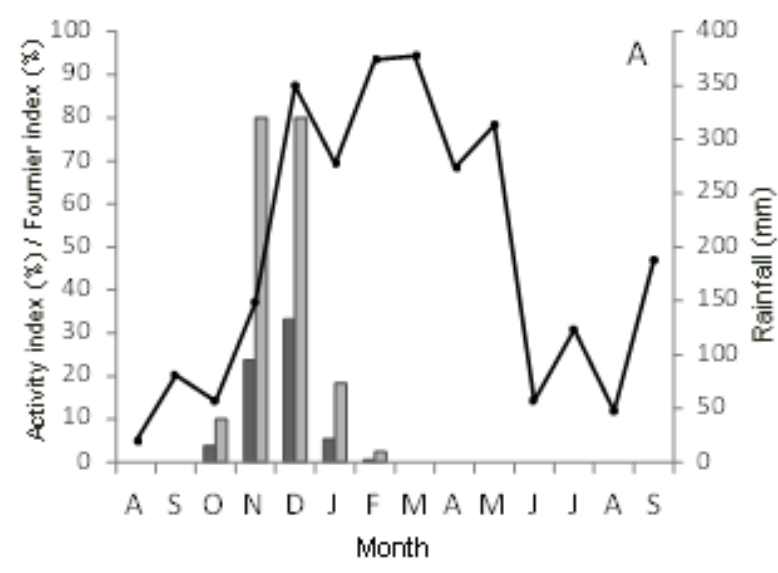

aFOURNIER $\quad$ aACTIVITY

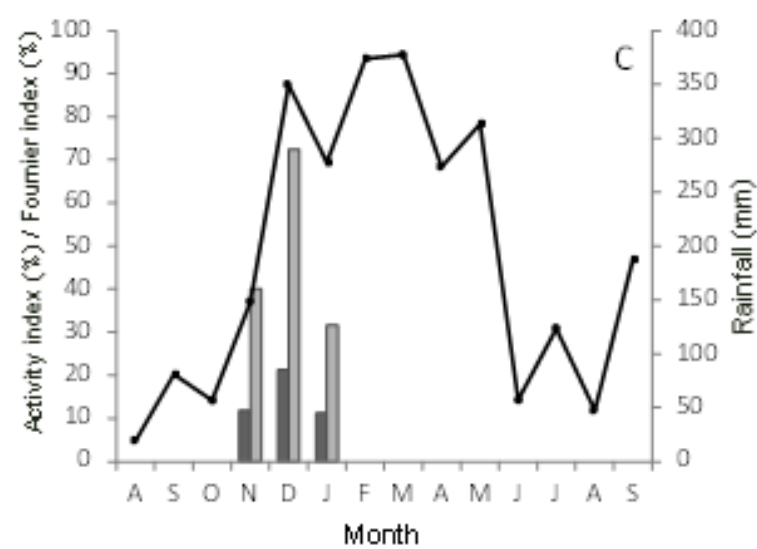

FOURNIER

口ACTIVITY

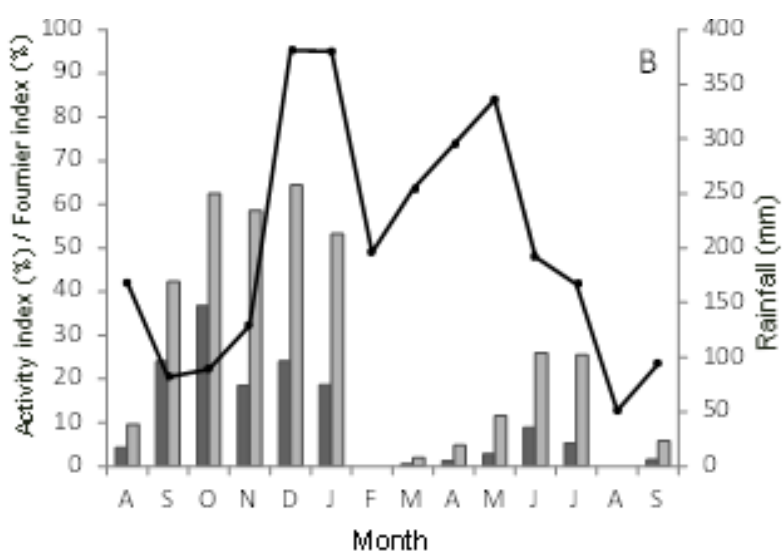

a FOURNIER GACTIVITY

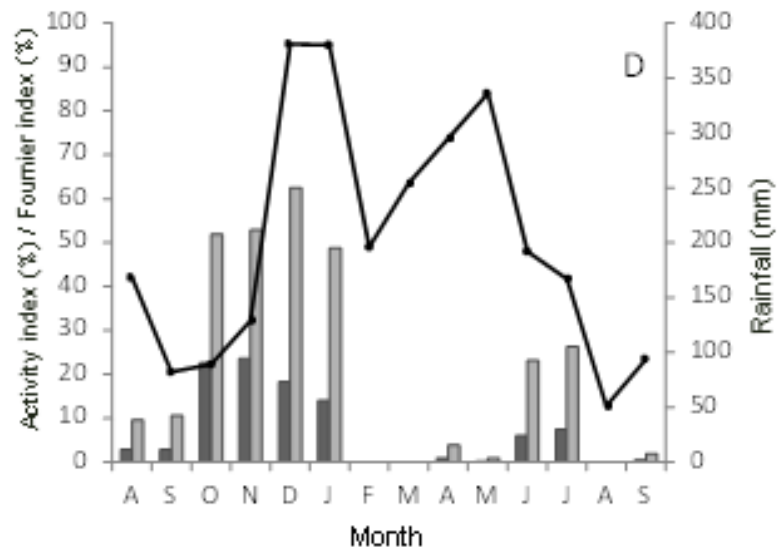

口ACTIVITY

Figure 3. Flowering phenology of camu-camu, Myrciaria dubia from August 2018 to September 2019 in two populations in Amazonas state, Brazil, shown as the activity index and the Fournier index for flowering phases. A, C - natural population on a floodplain terrain; B, D - plantation on terra firme; $A, B$ - flower buds; C, D - flowers. The line shows the monthly rainfall.

reached their highest values (Figure 3d). Some individuals bloomed during the warmer months of September $\left(36^{\circ} \mathrm{C}\right)$, October $\left(36.9^{\circ} \mathrm{C}\right)$ and November $\left(36.4^{\circ} \mathrm{C}\right)$, and others did so during the transition between high rainfall and falling temperatures in December $\left(33.1^{\circ} \mathrm{C}\right)$. A second, lower intensity, flowering peak followed in June $\left(33.8^{\circ} \mathrm{C}\right)$ and July $\left(34.1^{\circ} \mathrm{C}\right)$, a period with slightly lower temperatures and moderate rainfall. Flowering showed a gradual increase from October to the peak in December, and then declined rapidly before beginning to flower again in April (Figure 3d).

\section{Fruiting}

In the natural population, green fruit production was observed between December and March, when the river began to rise and production gradually increased until reaching a peak in February, with a subsequent slow decline (Figure 4a). In contrast, green fruits were produced continually in the plantation, with constant monthly activity of around $11 \%$ of individuals. The highest activity and Fournier index for fruit production occurred simultaneously, between December and April (Figure 4b).

Ripe fruits were observed between January and May in the natural population. Production peaked in March, when almost all individuals had ripe fruit. In May there was an abrupt decline in production, followed by the absence of mature fruit in the following month (Figure 4c). In the plantation, ripe fruits were observed year-round in above $12 \%$ of individuals per month. The highest percentage and intensity of fruit production occurred simultaneously, between January and April (Figure 4d).

In the natural population, ripe-fruit drop occurred between January and April. The maximum activity index was $25 \%$ of individuals in February (Figure 4e). In the plantation, ripe fruits were observed falling in almost every month, except August (Figure 4f). 

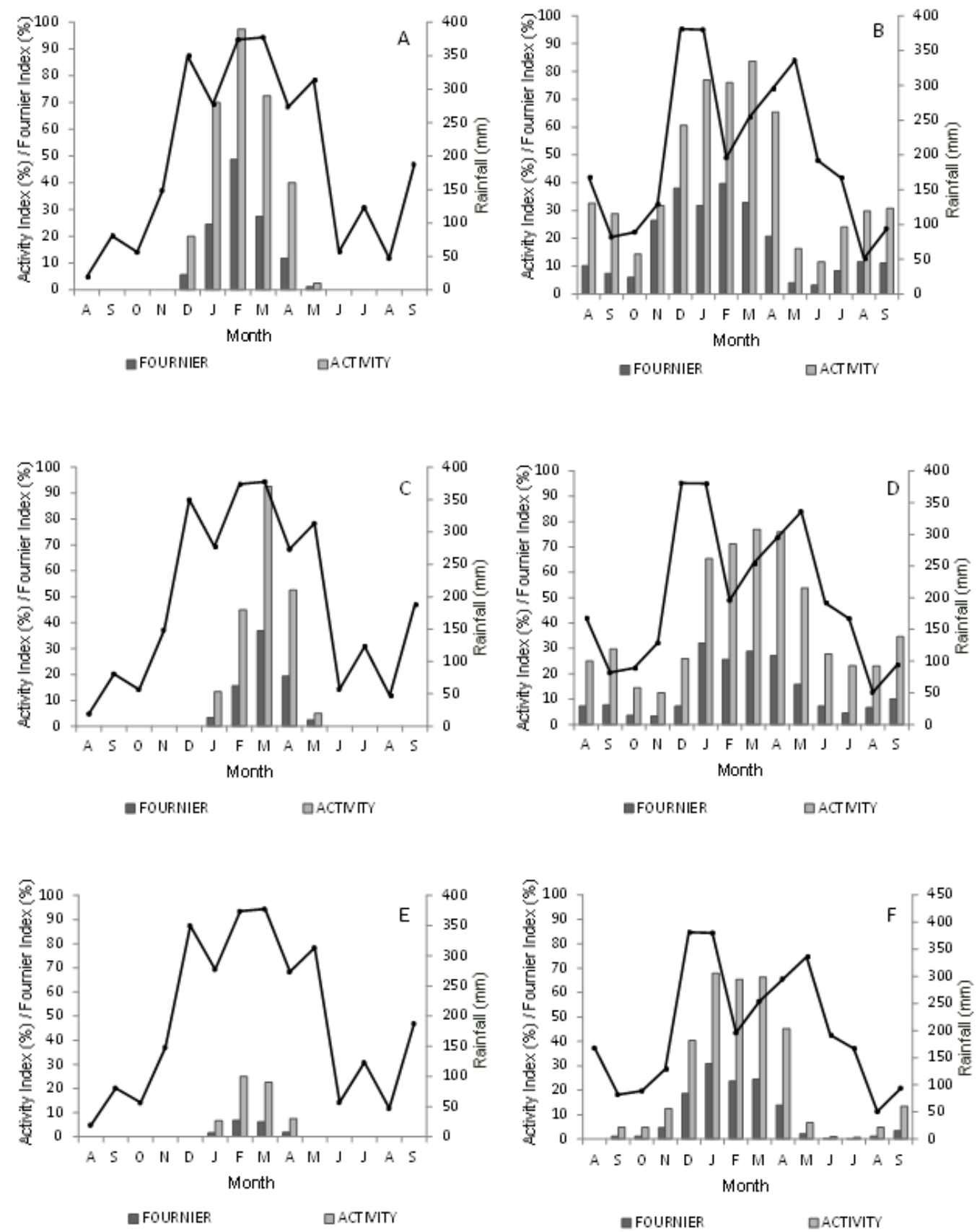

Figure 4. Fruiting phenology of camu-camu, Myrciaria dubia from August 2018 to September 2019 in two populations in Amazonas state, Brazil, shown as the activity index and the Fournier index for fruiting phases. A, C, E - natural population on a floodplain terrain; B, D, F - plantation on terra firme; $A, B$ - green fruits; $C, D$ - mature fruits; E, F- drop fruits. The line shows the monthly rainfall.

\section{Leaf phenology}

In the natural population, the greatest variations in the Fournier index were associated with leaf phenology. In August 2018, the shrubs had a high incidence of new leaf flush, which then decreased over subsequent months. From February to April, during rainfall peaks, monitored individuals almost exclusively bore mature leaves. As the water level subsided, the shrubs lost their leaves. From May onwards, intensity of new leaf production began to increase (Figure 5a).

In the plantation, the Fournier index for mature leaf intensity was almost always higher than that of new leaves. August and September 2019 were the only months when the opposite occurred, driven by a peak in new leaf production. Partial leaf loss occurred in all the months, with little variation 

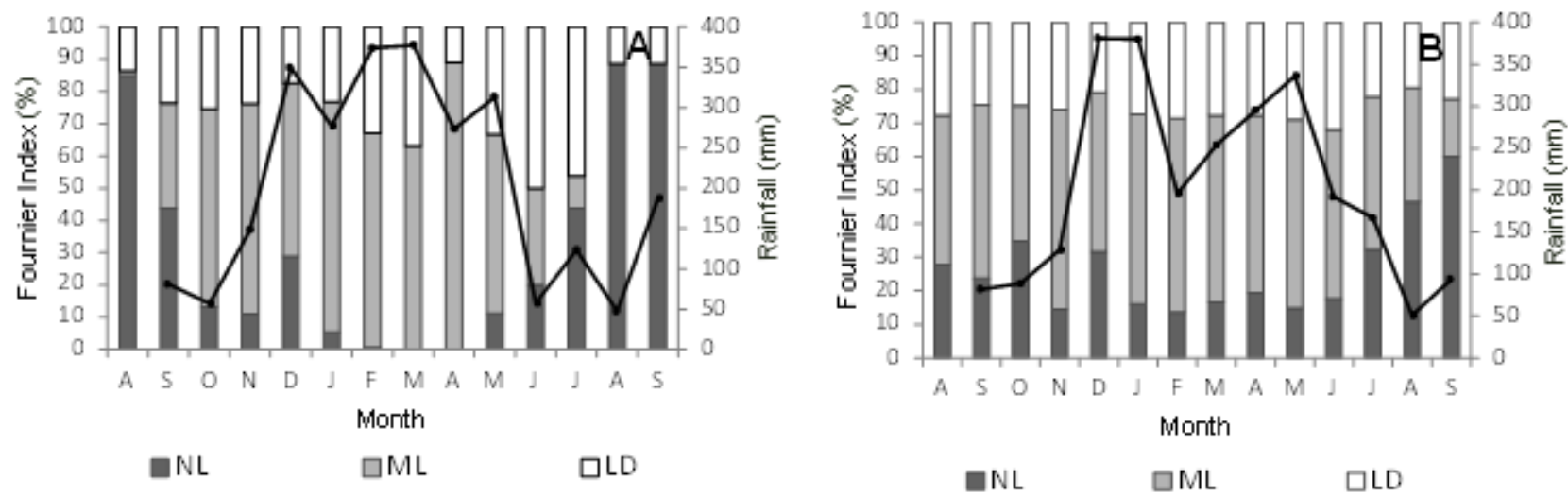

Figure 5. Leaf-drop phenology of camu-camu, Myrciaria dubia from Auqust 2018 to September 2019 in two populations in Amazonas state, Brazil shown through the Fournier index. A - natural population on a floodplain terrain; B: plantation on terra firme. NL - new leaves; ML - mature leaves; LD - leaf drop. The line shows the monthly rainfall.

among individuals and an average monthly leaf loss of approximately $35 \%$ (Figure $5 \mathrm{~b}$ ).

In the natural population, flowering was linearly related to temperature and relative humidity, with fruiting linearly related to rainfall. In the plantation, flowering was linearly related to rainfall and relative humidity, and fruiting was linearly related to rainfall, relative humidity and temperature. The effects were strongest for camu-camu in the plantation, where more environmental variables were significantly related to phenophases (Table 1).

\section{Fruit production}

After flower buds were marked in December, the second evaluation after fifteen days, in January, recorded 361 fruits in formation in the natural population and 304 in the plantation. In the natural population, 60 ripe fruits were collected between February and March, resulting in a fruiting success rate of $0.06 \%$. In the plantation, 20 fruits were collected

Table 1. Parameters of linear mixed effects (Ime) models to assess the effects of rainfall, temperature and relative humidity on flowering and fruiting in two populations of camu-camu, Myrciaria dubia. C. flowering and C. fruting: coefficient of fixed effects.

\begin{tabular}{|c|c|c|c|c|c|c|}
\hline Study site & C. flowering & F-value & $p$-value & C. fruiting & F-value & $p$-value \\
\hline \multicolumn{7}{|l|}{$\begin{array}{l}\text { Natural } \\
\text { population }\end{array}$} \\
\hline Rainfall & 0.001 & 30.58 & $>0.001$ & 0.001 & 171.06 & $<0.001$ \\
\hline Temperature & 0.078 & 62.25 & $<0.001$ & 0.047 & 16.08 & $>0.001$ \\
\hline $\begin{array}{l}\text { Relative } \\
\text { humidity }\end{array}$ & 0.010 & 40.97 & $<0.001$ & 0.001 & 114.74 & $>0.001$ \\
\hline \multicolumn{7}{|l|}{ Plantation } \\
\hline Rainfall & 0.005 & 28.71 & $<0.001$ & 0.001 & 131.95 & $<0.001$ \\
\hline Temperature & 0.013 & 4.84 & $>0.001$ & 0.081 & 140.45 & $<0.001$ \\
\hline $\begin{array}{l}\text { Relative } \\
\text { humidity }\end{array}$ & 0.004 & 13.08 & $<0.001$ & 0.014 & 96.54 & $<0.001$ \\
\hline
\end{tabular}

between January and February, resulting in a fruiting success rate of $0.02 \%$. Overall, the 80 fruits resulted in a mean fruit set rate of $0.04 \%$.

In the natural population seed number and fruit weight varied more than fruit diameter (Table 2). Spearman's correlation coefficient $(S)$ between fruit size and weight was positive and highly significant $\left({ }_{r} S=0.96, p<0.01\right)$. In the plantation, fruit weight varied more than other parameters (Table 2). Spearman's correlation coefficient $(S)$ between fruit size and weight was positive and highly significant $\left({ }_{\mathrm{r}} \mathrm{S}=\right.$ $0.90, \mathrm{p}<0.05)$.

Most of the fruits harvested on the plantation were classified as light or medium, while in the natural population the majority were heavy, with one to four seeds (Figure 6). Fruits of individuals in the natural population were the only ones to have three or four seeds, but most had two (about $48 \%)$. In the plantation one-seeded fruits predominated.

Table 2. Weight and diameter of fresh fruits and number of seeds per fruit in camu-camu, Myrciaria dubia collected in a natural population and plantation in Amazonas state, Brazil. Values are the mean \pm standard deviation followed by the minimum and maximum; $\mathrm{CV}=$ coefficient of variance; $\mathrm{N}$ seeds = number of seeds.

\begin{tabular}{lcccc}
\hline Aspect & Mean \pm SD & Min & Max & CV (\%) \\
\hline Natural population & & & & \\
\hline Fruit weight (g) & $6.07 \pm 2.18$ & 1.21 & 10.87 & 35.88 \\
\hline Fruit diameter (cm) & $2.14 \pm 0.33$ & 1.20 & 2.73 & 15.27 \\
N seeds & $1.68 \pm 0.77$ & 1 & 4 & 46.32 \\
\hline Plantation & & & & \\
\hline Fruit weight (g) & $3.62 \pm 1.55$ & 1.14 & 6.71 & 42.93 \\
Fruit diameter (cm) & $1.82 \pm 0.36$ & 1.01 & 2.60 & 20.07 \\
N seeds & $1.05 \pm 0.24$ & 1 & 2 & 22.91 \\
\hline
\end{tabular}



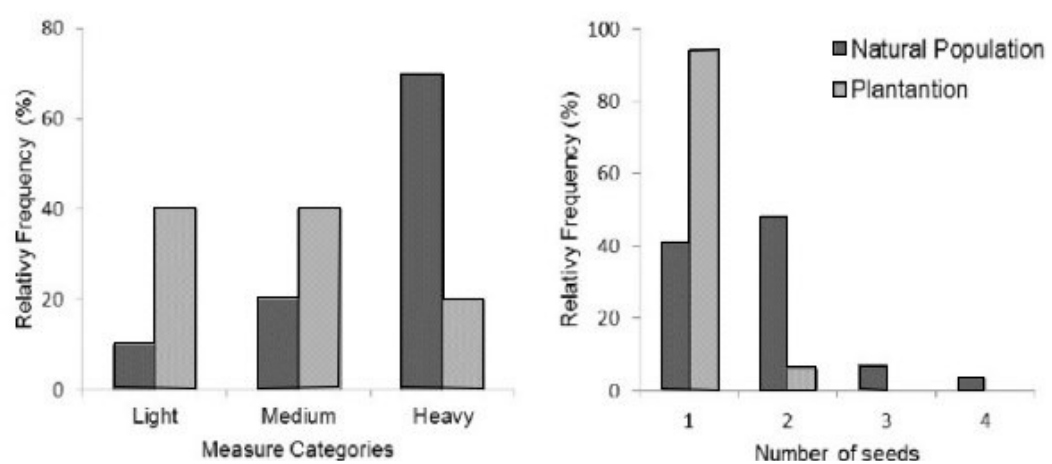

Figure 6. Variation of weight and diameter and seed number in camu-camu, Myrciaria dubia fruits collected in a natural population and a plantation in Amazonas state, Brazil. The line shows the monthly rainfall.

\section{DISCUSSION}

Synchrony was greatest in plants in the natural population, while the environmental variables analyzed had a greater influence on the phenophases in the plantation, where temperature and relative humidity were correlated with flowering. The higher the temperature, the more flower loss occurred (Farro et al. 2010). Phenology in the natural population depended on the river level, as natural flowering occurs when the water level is low, exposing the branches to the sun (Rodrigues et al. 2001). Thus, although the rainiest month was March 2019, and the relative humidity is generally high, this did not correlate with the increased production of buds or flowers, as some of the shrubs were already partially submerged.

The Fournier index for fruit presence was higher than the index for flower presence in both areas. This is probably due to the short flowering duration in camu-camu (one day) (Maués and Couturier 2002), so that some flowering events were likely missed as a result of the 14-day intervals between sampling sessions. In February, the number of plants with green fruits in the natural population had increased by $90 \%$ when compared to January, coinciding with a rise in river level. In March, 90\% of marked fruit were ripe, indicating that the rate of loss during maturation was small. Fruits are expected to ripen during the flooding period, since fish seem to be the main natural dispersers of camu-camu (Yuyama and Siqueira 1999).

Although camu-camu is a native floodplain species, fruit production in the terra firme plantation occurred throughout the year, suggesting that this species has managed to adapt effectively to this habitat. In Peru, individuals planted in 1997 had highest yields in the first few years, with a subsequent decrease. This was due to competition for space, light and nutrients, which was corrected with manual and chemical pruning, and fertilization, producing positive results for flowering and fruit production per plant (Abanto-Rodriguez et al. 2014). The systematic and regular adoption of these practices in cultivation can prevent decreases in productivity.
The natural population was reproductively active during a four-month period in 2019, and maximum fruit-bearing capacity (activity index $=25 \%$ ) coincided with the maximum height of the river, a relationship which has also been noted in other floodplain species (Kubitzki and Ziburski 1994). This activity index was much lower than that recorded during fruiting peak in the terra firme plantation, which is likely due, at least in part, to the difficulty in evaluating this phenophase in the flooded habitat of the natural population, where a good part of the ripe fruit fell into the water, where, most probably, they were rapidly consumed by fish (Yuyama and Siqueira 1999).

At both sites, plants continuously lost a portion of their leaf cover over the course of several months, a behavior also described by Maués and Couturier (2002) for populations in Belém, in the neighboring state of Pará, indicating that the species is semi-deciduous. In the natural population, the majority of leaves were lost at the peak of flooding, when plants were partially or totally submerged. Leaf loss is a common response to flood-based hydric stress ( $\mathrm{Xu}$ et al. 2010). At the terra firme plantation site, leaf change was much more uniform across the study period, with leaf loss and replacement recorded in all months, thus differing from the pattern observed in the natural population.

Our sampling design implies that a portion of the mature fruits that fell to the ground in the 14-day period between visits were lost, resulting in an underestimation of fruit production in both areas. In the natural population, all fruit that fell from flooded plants were lost. In the plantation, other undetermined factors could have lead to fruit loss, such as physiological and nutritional aspects, and the impacts of competition, wind and rain (Farro et al. 2010). Even so, production was three times greater in the natural population. Similar results were observed by Maués and Couturier (2002) for camu-camu populations in Pará, when comparing data from cultivated plants with that of natural populations provided by Peters and Vasquez (1987). In camu-camu under 
cultivation in Peru, only $25 \%$ of the fruits reached maturation, even though the population produced large numbers of ripe fruits, as abortion rates per individual were high, reducing total production potential (Farro et al. 2010).

Most fruits were ready to be harvested three months after flower bud marking, which lies within the expected developmental period of 70 to 100 days (Castro et al. 2018). In the plantation, while the largest fruits were harvested four months after marking, these were smaller than those from the natural population. In Melastomataceae, the dynamics of pollinator visits influence reproductive success (Fracasso and Sazima 2004), which may also occur in other tropical families. In our camu-camu sites, the higher fruit production in the natural population could be related to that pollination was more efficient in this area.

In the plantation, fruit production occurred in all the months of the study, although in a non-uniform way, as the highest production occurred during the five months of moderate to highest rainfall, with peaks that mirrored the phonological cycle observed in the natural population. Water availability is essential for the development of fleshy fruits (Araújo et al. 2009), which explains the higher yield in the rainier months in terra firme. The provision of an irrigation system for the camu-camu terra firme cultivation may be necessary to improve production. Fruit production may also be restricted by plant nutritional status, an aspect which should be investigated in future studies to test whether there is a lack or excess of nutrients, such as phosphorus, in the soil on which these plants are growing (Martinez et al. 2003; Malhotra et al. 2018).

In the natural population site, rainfall remained high between December and May, while at the terra firme site, rainfall declined over the same period, and this may have generated water stress and contributed to lower productivity. Such events can directly influence fruit production (Berman and DeJong 1996). In addition, transpirational water loss is also an important component of water balance in fruits of some species, and is important in determining harvest quality criteria, including fruit size (Lescourret et al. 2000).

Combining data from both areas, fruit weight varied from 1.14 to $10.87 \mathrm{~g}$, lower values than those found in native populations in the northern Brazilian state of Roraima (Yuyama et al. 2002). As with other plant species, such extensive variation may be associated with geographic variation in genetic makeup, degree of maturation and environmental characteristics (Gusmão et al. 2006). In addition, camucamu is pollinated primarily by bees, which are sensitive to environmental changes (Peter and Vazquez 1987; Maués and Couturier 2002; Oliveira et al. 2014). In camu-camu, a high diversity of native bees has been associated with higher productivity (Delgado et al. 2020). In a comparative study between naturally occurring and cultivated açaí palms (Euterpe oleracea Mart.), the density of native bees was lower in sites under cultivation, which may have affected fruit production (Campbell et al. 2018). This may also have been the case in our study. Another consideration is that plants can regulate their energy budget (Moura et al. 2010) and how the energy is allocated to fruit and seed production, e.g. by producing smaller fruits over longer periods, as occurred in the terra firme plantation.

For seed number, the minimum number of pollen grains required for maximum seed production per fruit under natural conditions is equal to the maximum number of seeds (Ne'eman et al. 2010). Consequently, it is likely that camucamu pollinators at the plantation site may not use all the available pollen and the prior or simultaneous deposition of self-incompatible or closely-related pollen may interfere with the ability of plants to use better quality pollen, resulting in reduced seed set (Ramsey and Vaughton 2000).

Information on the biometric variation of fruits is important for crop improvement and development of cultivars to enhance fruit size and quality for commercialization (Zuffo et al. 2014). To increase production further in camucamu terra firme plantations, it will be important to select individuals that produce fruits with the largest size and greatest number of seeds. Since camu-camu is native to the Amazon region, it can become a source of income for local producers, and thereby benefit the regional economy.

Another important factor is the variation in the ascorbic acid concentration in camu-camu, which is low in green fruits and gradually increases as the fruit matures (Yuyama et al. 2002). In addition to checking ripeness via pericarp color, the positive correlation between weight and size showed that the fruits can also be selected by either one of these variables, as ripe fruits with larger diameter and weight are more commercially attractive.

The information generated in this study can also be used to plan sustainable management practices to improve fruit yield in terra-firme plantations, e.g., by planning weed management (Ghersa 2010). We observed far more weeds in the plantation than in the natural populations.

\section{CONCLUSIONS}

Based on our results, we can conclude that camu-camu develops well as a crop cultivated in terra firme, but shows much potential for improvement comparing to the productivity of naturally occurring plants from the floodplain. The adoption of different management measures may be necessary to increase plantation productivity, such as the implementation of an irrigation system, since camu-camu flowering and fruiting are conditioned to climatic factors such as rainfall and relative humidity. The data generated in this study will be used as part of a management plan by the 
Empresa Brasileira de Pesquisa Agropecuária (EMBRAPA) and will be made available to producers throughout the region.

\section{ACKNOWLEDGMENTS}

We are grateful for the use of the infrastructure of Instituto Nacional de Pesquisas da Amazônia (INPA), especially of the graduate program in Botany (PPG-BOT). This study was financed in part by Coordenação de Aperfeiçoamento de Pessoa de Nível Superior - Brasil (CAPES), Finance Code 001. Financial support for this study was received from the project "Rede de Interaçôes de abelhas com frutíferas do Norte e Nordeste (PoliNet)" (code SEG 02.16.04.024.00.00) financed by Empresa Brasileira de Pesquisa Agropecuária. We are also very grateful for valuable contributions made by the anonymous reviewers.

\section{REFERENCES}

Abanto-Rodriguez, C.; Pinedo-Panduro, M.; Bardales-Lozano, R.; Alves-Chagas, E. 2014. Efecto de la poda de fructificación y defoliación en el proceso productivo de camu camu en la región Ucayali-Perú. Folia Amazonica, 23: 17-24.

Araújo, R.R.; Santos, E.D.; Lemos, E.E.P.; Alves, R.E. 2009. Caracterização biométrica de frutos e sementes de genótipos de murici (Byrsonima verbascifolia (L.) Rich.) do Tabuleiro Costeiro de Alagoas. Revista Caatinga, 22: 224-228.

Barros, H.R.M.; Moura, M.H.C.; Araújo, R.L.; Genovese, M.I. 2018. Bioactive compounds of Camu-Camu (Myrciaria dubia McVaugh), the super fruit from the amazon region: chemical characterization and biological activity. In: Todorov, S.D.; Pieri, F.A. (Ed.). Tropical Fruits: From Cultivation to Consumption and Health Benefits. Nova Science Publishers, New York, p.153-186.

Bencke, C.S.C.; Morellato, P.C. 2002. Comparação de dois métodos de avaliação da fenologia de plantas, sua interpretação e representação. Revista Brasileira de Botânica, 25: 269-275.

Berman, M.E.; DeJong, T.M. 1996. Water stress and crop load effects on fruit fresh and dry weights in peach (Prunus persica). Tree Physiology, 16: 859-864.

Campbell, A.J.; Carvalheiro L.G.; Maués M.M; Jaffé, R.; Giannini, T.C.; Freitas, M.A.B; Coelho, B.; et al. 2018. Anthropogenic disturbance of tropical forests threatens pollination services to açaí palm in the Amazon river delta. Journal of Applied Ecology, 55: 1725-1736.

Castro, J.C.; Maddox, J.D.; Imán, S.A. 2018. Camu-camu — Myrciaria dubia (Kunth) McVaugh. In: Rodrigues, S.; Silva, E.; Brito, E. (Ed.). Exotic Fruits. Academic Press, Massachusetts, p. 97-105.

Chagas, E.A.; Flores, P.S.; Chagas, P.C.; Couceiro, M.A.; Pasqual, M.; Pio, R.; et al. 2014. Frutíferas nativas da Amazônia. In: Pasqual, M.; Chagas, E.A. (Ed.). Cultura de Tecidos em Espécies Frutiferas. Editora da UFRR, Boa Vista, p.89-109.

Delgado, C.; Rasmussen, C.; Mejía, K. 2020. Asociación entre abejas sin aguijón (Hymenoptera: Apidae: Meliponini) y camu camu (Myrciaria dubia: Myrtaceae) en la Amazonía peruana. Livestock Research for Rural Development, 32: \#129. http://www.lrrd.org/ lrrd32/8/cdelga32129.html
Farro, S.; Pinedo, M.; Huaranca, R. 2010. Possible factors which produce fruit drop of Myrciaria dubia (HBK) Mc Vaugh, "camu camu" during the reproductive phenology in the collection "cinco cuencas" from the San Miguel experimental center, Loreto, Peru. Scientia Agropecuaria, 1: 117-123.

Fournier, L.A. 1974. Un método cuantitativo para la medición de caracteristicas fenológicas en árboles. Turrialba, 24: 422-423.

Fracasso, C.M.; Sazima, M. 2004. Polinização de Cambessedesia hilariana (Kunth) DC. (Melastomataceae): Sucesso reprodutivo versus diversidade, comportamento e freqüência de visita de abelhas. Revista Brasileira de Botânica, 27: 797-804.

Ghersa, C.M. 2000. Plant phenology and the management of cropweed interactions. Field Crops Research, 67: 91-93.

Gusmão, E.; Vieira, F. A.; Júnior, E. M. F. 2006. Biometria de frutos e endocarpos do murici (Byrsonima verbascifolia Rich. ex. A. Juss). Cerne Lavras, 12: 84-91.

INMET. 2019. Instituto Nacional de Meteorologia. BDMEP - Banco de Dados Meteorológicos para Ensino e Pesquisa. (www.inmet.gov. br/portal/index.php?r=bdmep/bdmep). Acessed on 02 Dec 2019.

Köppen, W. 1948. Climatologia: Con un Estudio de los Climas de la Tierra. Fondo de Cultura Económica, México, 478p.

Kubitzki, K.; Ziburski, A. 1994. Seed dispersal in flood plain forests of Amazonia. Biotropica, 26: 30-43.

Lescourret, F.; Génard, M.; Habib, R.; Fishman, S. 2001. Variation in surface conductance to water vapor diffusion in peach fruit and its effects on fruit growth assessed by a simulation model. Tree Physiology, 21: 735-741.

Malhotra, H.; Vandana; Sharma, S.; Pandey, R. 2018. Phosphorus Nutrition: Plant Growth in Response to Deficiency and Excess. In: Hasanuzzaman, M.; Fujita, M.; Oku, H.; Nahar, K.; Hawrylak-Nowak, B. (Ed.). Plant Nutrients and Abiotic Stress Tolerance. Springer, Singapore, p.171-190.

Marques, M.C.M.; Oliveira, P.E.A.M. 2004. Fenologia de espécies do dossel e do sub-bosque de duas Florestas de Restinga na Ilha do Mel, sul do Brasil. Revista Brasileira de Botânica, 27: 713-723.

Martinez, H.E.P.; Clemente, J.M.; Lacerda, J.S.; Neves, Y.P.; Pedrosa, A.W. 2014. Nutrição Mineral do cafeeiro e qualidade da bebida. Revista Ceres, 61: 638-648.

Maués, M.M.; Couturier, G. 2002. Biologia floral e fenologia reprodutiva do camu-camu (Myrciaria dubia (H.B.K.) McVaugh, Myrtaceae) no Estado Pará, Brasil. Revista Brasileira de Botânica, 25: 441-448.

Moura, T.M.; Oliveira, G.C.X.; Chaves, L.J. 2010. Correlaçấo entre floração, frutificação e variáveis ambientais em Solanum lycocarpum. a. st. hil, Solanaceae. Bioscience Journal, 26: 457-462.

Ne'eman, G.A.; Jürgens, L; Newstrom-Lloyd; Potts, S.G; Dafni, A. 2010. A framework for comparing pollinator performance: effectiveness and efficiency. Biological Reviews of the Cambridge Philosophical Society, 85: 435-451.

Oliveira, M.A.; Gomes, C.F.F.; Pires, E.M.; Marinho, C.G.S.; Della Lucia, T.M.C. 2014. Bioindicadores ambientais: insetos como um instrumento desta avaliaçáo. Revista Ceres, 61: 800-807.

Peters, C.M.; Vasquez, A. 1987. Estudios ecológicos de camu-camu (Myrciaria dubia). I. Producción de frutos en poblaciones naturales. Acta Amazonica, 16/17: 161-174. 
Pinheiro, J.; Bates, D.; DebRoy, S.; Sarkar, D; R Core Team. 2007. Linear and Nonlinear Mixed Effects Models. R package version 3.1-131. (CRAN.Rproject.org/package=nlme). Accessed on 15 Dec 2019.

Pinto, C.E.D.L.; Fajardo J.D.V; Taube, P.S.; Sacramento, J.A.A.S.; Barros, E.C. 2020. Initial production and quality of camucamu fruits under organic and mineral fertilization. Pesquisa Agropecuaria Tropical, 50: e60821.

Pires, J.M.; Prance, G.T. 1985. The vegetation types of the Brazilian Amazon. In: Prance, G.T.; Lovejoy, T.E. (Ed.). Key Environments: Amazonia. Pergamon Press, Oxford, p.109-145.

R Development Core Team. 2012. R: A Language and Environment for Statistical Computing. R Foundation for Statistical Computing, Vienna, Austria. (www.R-project.org/). Accessed on 15 Dec 2019.

Ramsey, M.; Vaughton, G. 2000. Pollen quality limits seed set in Burchardia umbellata (Colchicaceae). American Journal of Botany, 87: 845-852.

Rodrigues, R.B.; Menezes, H.C.; Cabral, L.M.C.; Dornier, M.; Reynes, M. 2001. An Amazonian fruit with a high potencial as a nature source of vitamina C: the camu-camu (Myrciaria dubia). Fruits, 56: 345-354.

Segantini, D.M.; Torres, L.M.; Boliani, A.C.; Leonel, S. 2010. Fenologia da figueira-da-índia em Selvíria-MS. Revista Brasileira de Fruticultura, 32: 630-636.

Silva, W.G.; Oliveira, M.N. 2018. Edible popular fruit in the Amazon region: food importance. In: Todorov, S.D.; Pieri, F.A. (Ed.). Tropical Fruits: From Cultivation to Consumption and Health Benefits. Nova Science Publishers, New York, p.1-24.
Vidigal, M.C.T.R; Minim, V.P.R.; Carvalho, N.B.; Milagres, M.P. Gonçalves, A.C.A. 2011. Effect of a health claim on consumer acceptance of exotic Brazilian fruit juices: Açaí (Euterpe oleracea Mart.), Camu-camu (Myrciaria dubia), Cajá (Spondias lutea L.) and Umbu (Spondias tuberosa Arruda). Food Research International, 44: 1988-1996.

Wallace, R.B.; Painter, R.L.E. 2002. Phenological patterns in a southern Amazonian tropical forest: implications for sustainable management. Forest Ecology and Management, 160: 19-33.

Xu, Z.; Zou, G.; Shimizu, H. 2010. Plant responses to drought and rewatering. Plant Signaling \& Behavior, 5: 649-654.

Yuayama, K.; Siqueira, J.A.S. 1999. Efeitos do tamanho da semente e do recipiente no crescimento de mudas de camu-camu (Myrciaria dubia). Acta Amazonica, 29: 647-650.

Yuyama, K.; Aguiar, J.P.L.; Yuyama, L.K. O. 2002. Camu-camu: Um fruto fantástico como fonte de vitamina C. Acta Amazonica, 32: 169-174.

Zuffo, A.M.; Andrade, F.R.; Júnior, J.M.Z. 2014. Caracterização biométrica de frutos e sementes de baru (Dipteryx alata Vog.) na região leste de Mato Grosso, Brasil. Revista de Ciências Agrárias, 37: 463-471.

RECEIVED: $20 / 02 / 2020$

ACCEPTED: 02/03/2021

ASSOCIATE EDITOR: Carolina V. Castilho 